\title{
COLLOQUIA
}

GEORG RITZER

University College of Teacher Education

Forum Pedagogiczne

Salzburg

Austria

$9(2019) 2$, cz. 2

Wpłynęło: 20.09.2019

ORCID ID: http://orcid.org/oooo-0oo2-4144-0024

Zatwierdzono do druku: 20.11.2019

DOI: $10.21697 / \mathrm{fp} .2019 .2 .38$

\section{ETHICAL AND MORAL ARGUMENTS. INSIGHTS INTO A VALIDATION STUDY OF THE ETIK-TEST}

\begin{abstract}
The following article deals with ethical-moral argumentation patterns of pupils. The underlying question is whether pupils' answers to tasks in the ETiK-Test correspond with the theoretical considerations of the test constructors. This instrument aims to measure ethical-moral competences of pupils, based on education-theoretical, ethical and subjectdidactical considerations.

After the presentation of the theoretical concept of the ETiK-Test, the empirical qualitative method of this study is shortly described. By way of example, the procedure is shown in two tasks. Then an overview of forms of argumentations that pupils use to justify their answers is presented.

The investigation has shown that central theoretical assumptions of the test constructors are found in pupils' discussions. Some response patterns are not found in the theoretical concept of ETiK-Test. Sometimes incorrect response patterns can lead to correct answers and correct response patterns can lead to wrong answers.
\end{abstract}

Keywords: ethical-moral competences; ETiK-Test; content-related validation; ethic education.

\section{Introduction}

In almost all European countries, ethics education is offered as a subject at schools. In 11 European countries Ethics lessons are compulsory or elective, as in Poland (Stępkowski et al., 2016, Latvia, Iceland, Bulgaria, Slovakia, Finland, Slovenia, Germany, Belgium, Lithuania and Switzerland. In Czech Republic, Estonia, France, Slovenia, Sweden and Croatia Ethics is not a subject of instruction, but it is managed as part of a compulsory subject. In Germany the offering of Ethics depends on the individual regions (Fuß et al., 2016), in most countries pupils, who do not take part in religious education, have to take Ethics. (BMUKK, 2012) In Austria Ethics is still a school experiment at few schools. (Ritzer et al., 2016) 
In this article, the consensus on the importance of the subject Ethics (Bucher, 2017) is assumed. But international comparative studies such as PISA or TIMSS see the risk that the so-called soft subjects, such as ethics, are becoming less important because instruments for measuring output are largely absent. (Nikolova, 2016) On this background it is expedient to elaborate a test that deals with the measurement of ethical competencies. Therefore a research group led by Dietrich Benner has developed a test called "ETiK" that aims to measure ethical competencies. (Benner \& Nikolova, 2016) The validity of the test has been inspected by several quantitative studies. (Ivanov, 2016; Stępkowski et al., 2016) The following article is based on a detailed validation study with quantitative and qualitative designs. (Ritzer, 2019) In the qualitative investigation it is asked how students explain their test answers. Do the answers correspond to the theoretical considerations of the instrument? In the following text references are made to this qualitative research. Two tasks and the corresponding answers from pupils are presented as examples. The results have to be presented in an overview without references to the original texts. This article is about different types of pupils' responses.

\section{Theoretical framework and research questions}

For the German-speaking countries there are some studies dealing with the evaluation of ethics lessons. (Overview: Bucher, 2001; Nikolova, 2016) Most of these researches operate with self-assessments of respondents. The ETiK-Test uses methods of the Item Response Theory (IRT), in order to measure performance profiles of individual persons and to predict their problem-solving behaviour. The education-theoretical, ethical and subject-didactical considerations underlying the ETiK-Test are central to the construction of the various tasks. These credentials must be explained:

The ETiK-Test distinguishes between basic ethical-moral knowledge, ethical-moral decision competence and the ethical-moral competence to plan activities. Basic knowledge pertains to concepts of philosophical ethics that are relevant to contemporary living together. Decision competence is not restricted to knowledge, it deals with the reflection of moral challenges from different perspectives. The competence to plan activities helps to design moral decisions and to coordinate moral actions with other people (Benner, 2016). This distinction has been found empirically in the base line investigations. (Ivanov, 2016) In some pretests this differentiation was not possible. (Ivanov, 2016)

Further the test distinguishes in all three sub-competences between areas that are related to one's own morality, foreign morality and morality in public space.

Another distinction refers to the elemental judgements from Johann Friedrich Herbart. In essence, it clarifies ethical-moral norms and it can be found in all cultures. The first elementary decisions (inner freedom) state that moral decisions should not primarily act according to one's own will; one's own will should be questioned. This 
is the basis for all other elementary decisions that facilitate recognition of what one wants and what one does not want. This is about the ability to take the perspective of another person, to bring goodwill to the other. Furthermore, this is about settling disputes in accordance with legal principles and what is to be done if the agreed rights are violated. In such cases, a possibility of reparative justice should be found for the infringement. ( Herbart, 1808; Benner et al., 2015 Benner, 2016)

In regard to various forms of ethical-moral decisions the ETiK-Test differences between aporetic (certainties are called into question and new search movements are thereby made possible), periagogic (taking different perspectives), teleologic (arguments that ask for the goal), categoric (people are considered as an end in itself), critique of ideology (argument for a liberating morality), social criticism (questioning social conditions) and pragmatic (to argue and act wisely in consideration of different arguments) ways (Benner, 2016). One strength of the concept is that it does not favour a particular form of judgment. Purpose of teaching ethics is to empower pupils so that they can design actions individually, together with other people that can be called pragmatic and clever. This requires the ability to compare or relate judgments. (Benner \& Nikolova, 2016)

The following article deals with the question if pupils answer the tasks in the ETiK-Test, in the light of the theoretical considerations of the test constructors. The research questions are: (1) Do students understand the task? (2) Do students distance themselves from their own will in their answers? (3) Can we find aporetic, periagogic, teleologic, categoric, ideology critique, socially critical or pragmatic arguments in pupils' answers? Or are there other forms of reasoning?

\section{Methods}

Answering the research questions was part of two projects in Austria. These projects were dealing with qualitative and quantitative methods to validate the ETiK-Test. This article is about the qualitative part of the investigation. Pupils, age 15 to 16 , taking part in ethic lessons were broken down into small, three to five persons groups (Lamnek, 2010; Flick, 2016; Mayring 2016). They discussed six to eight tasks of the instrument in a school lesson. In this process, they had to argue their answers to the tasks. In total, 60 students in 18 groups discussed 33 tasks on ethical-moral competences.

The analysis is done according to the axial and open coding in the grounded theory (Strauss \& Corbin, 1996) and the content analysis (Mayring, 2010). Both approaches combine inductive and deductive approaches (Ritzer, 2019). The theoretical assumptions are set as preliminary categories. These categories are verified and supplemented if necessary. The data were analysed using the computer program Atlas ti (Friese, 2015). Further literature (for example: Pieper, 2007; Quante, 2013; Hübner, 2014) is used as the basis for naming, interpreting and delineating the newly found categories. 


\section{Selected results}

The following selected results refer to the research questions presented above.

Do students understand the task?

Analysing the difficulties in understanding the tasks, a distinction is made between two topics. On the one hand it is about explicit comments of pupils that point out incomprehensibility. On the other hand, it is about comments that implicitly point to misunderstandings of task content.

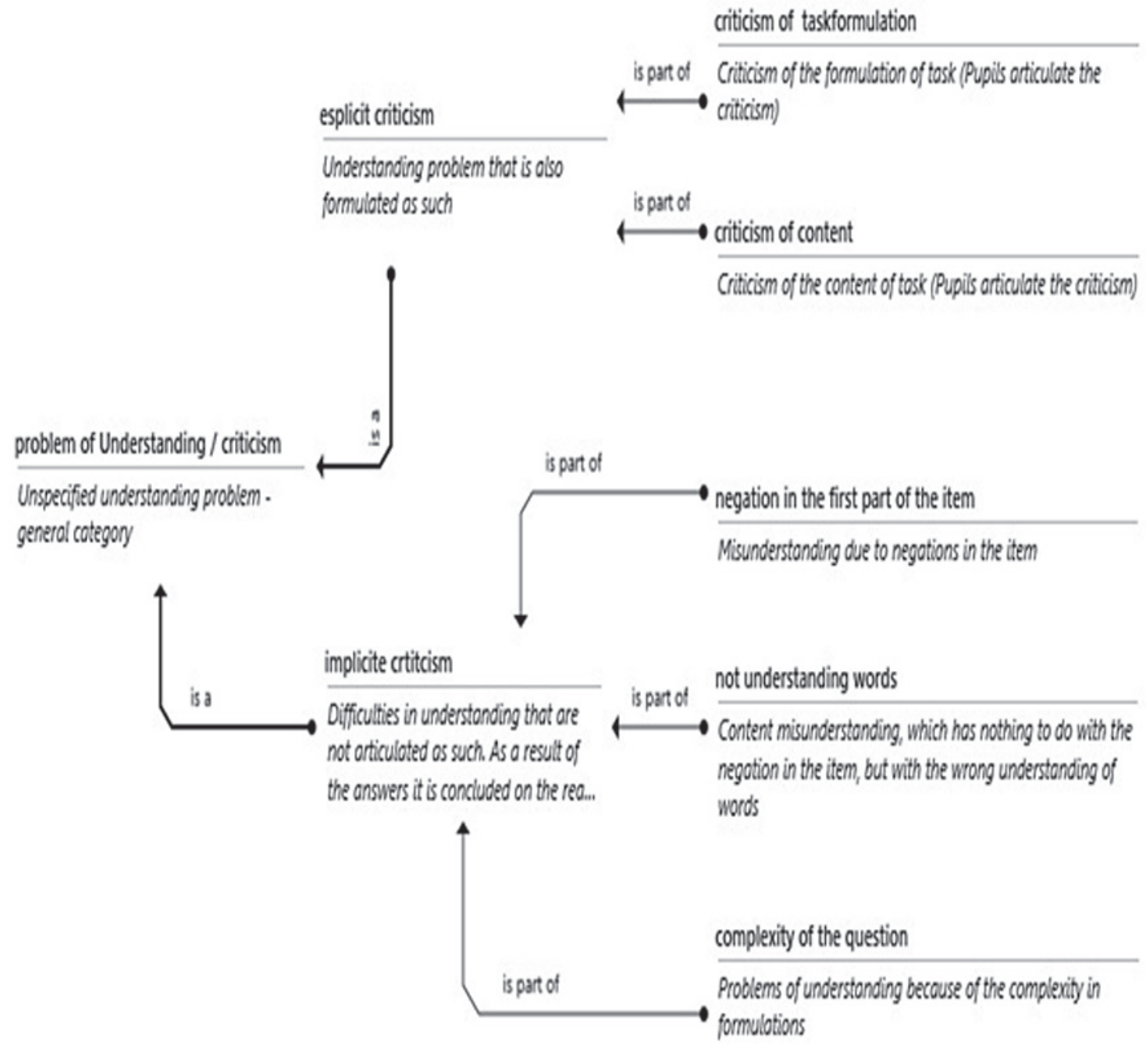

Fig. 1 Problems with understanding / criticism.

Source: own elaboration.

Problems with understanding are often found in tasks that contain a negation in the item. When the negation is neglected or misinterpreted, it can happen, that pupils answer the opposite of what is actually intended. Other implicit understanding problems are based on the misinterpretation of terms and contexts or the inability to solve tasks because of their complicated formulation. The complexity of tasks 
can also lead to explicit criticism. When pupils criticize the content of tasks, they say, that available answer options are not clear enough and in some tasks, there is too little background information to answer questions.

The procedure for answering the second research question is illustrated by two concrete tasks of the ETiK-Test. This should minimize the abstractness of the instrument and it should provide an insight into tasks.

The first of the presented tasks is part of the ethic-moral decision competence and the second task is part of the ethic-moral competence to plan activities.

In most of the tasks ( 24 from 33 ) the specific argumentation can be found which deals with the will of persons or the distance from the will.

The following task holds most of the codes regarding handling one's choices.

Today, it is generally believed that the right to a decent life includes the right to a dignified death. Hospices are institutions that accommodate people who are dying and look after them around the clock. Sometimes relatives help doing this. In order to relieve pain, drugs are also given in doses that can shorten the lifetime.

Which of the following situations (A-E) show...

[...] an appropriate way to deal with or

$[\ldots]$ not an appropriate way to deal with a terminally ill person?

A. The terminally ill person is washed every day the whole body, even if he does not want to.

B. The relatives and helpers take turns so that the terminally ill person always has someone nearby. The most important thing is, that he is never alone.

C. If the terminally ill person wants to be alone, the nurses have to leave the room, even at the risk that the patient could die lonely.

D. If the terminally ill person wants that, you have to talk to him about his funeral, even if it's a sad topic.

E. When the terminally ill person has intensive demands to a topic, you can lie to him, when the true answer would upset him.

The task was understandable for the pupils, at least there are no comments pointing out incomprehensibility or ambiguity. For this task many different arguments were formulated by the pupils. Basically the arguments of the pupils are distinguished in decision processes (ethical argumentations) and references to which respondents refer in their decisions (moral arguments). (Pieper, 2007) In terms of the second research question, the distancing of the own will is part of the references (moral argumentations). The ethic argumentations (aporetic, periagogic, teleologic, categoric, ideologycritic, socialcritic, pragmatic) are part of the processes of deciding. 
In the first scene, which is proposed in the presented task, the students weigh different perspectives and consider who wants what.

Most of the time, they decide that it should be acted according to the will of the dying person. Pupils consider what is more important in this situation. "Yes, he already needs to be washed. But then that is no longer his life / his quality, what he still wants to do. That's something trivial." (f. 16) ${ }^{21}$ In a categorical way the focus is on the terminally ill Person "Yes. And I can understand it, if he just does not feel like it." (m. 15)

In the second sentence ("The relatives and helpers take turns so that the terminally ill person always has someone nearby. The most important thing is, that he never is alone.") a point of discussion was the interpretation of the word "nearby". The pupils mainly use hermeneutic arguments, in which the answers are deduced from the task or from the interpretation of word meanings. discussing the density of nursing, an important consideration is, whether in the proximity also dignity and privacy is possible.

Pupils ask for the will of the patient und they orient their decisions categorically on the will of the terminally ill person. ("Because I think maybe he wants to be alone and think about death on his own"; [f. 15] "So I think that [...] is more appreciative if you do not leave him alone and if you are there for him." [m. 16]) The arguments on the third question are similar ("It's about how the terminally ill person is feeling." [f. 16]) In the fourth situation that was presented, pupils agreed that one should talk to the terminally ill person about the funeral if he wants to. Again, they argue that the will of the person must be respected.

In the last situation presented in the hospice-task, there was less consensus. Considering what is an appropriate way to deal with the problem, one pupil said, "Sometimes it's better to lie." (f. 15). Others were led by the rule, that in generally one should not lie. This is even more important, when dealing with a dying person. "Because, he has a right to the truth. No matter what condition he is in." (m. 16)

For one pupil this idea is emotionally nearly unbearable. She would sugarcoat information making it as painless as possible. "Then I would say: No, everything will be fine and so on. You do not need to get upset." (f. 15) According to the test designers, this form of consideration does not correspond to a dignified way of dealing with a dying person.

In summary, in this task the reasons for answers given by the pupils correspond to the theoretical assumptions of the test designers.

The second task which is presented here, deals with a girl called Lisa. Lisa is 15 years old and has a boyfriend, David (17). She realizes that she is pregnant without having planned it. She is unsettled and confused. The task is part of the ethicalmoral competence to plan activities and it refers to one's own morality.

21 "f" stands for female; „m" for male; the number indicates the age. The answers are translated from German. 
Lisa goes to the pregnancy counselling service. There she learns that she has more choices than giving birth to the child or aborting the pregnancy. She's learned that it is also possible to submit the child for adoption.

How has Lisa's moral scope changed by this information?

(There is a correct answer)

A. Lisa no longer can decide against her motherhood.

B. Lisa can give birth to the child without having to take on social responsibility for the child

C. Lisa now has time until the date of birth to make decision for or against abortion

D. Lisa now can opt for abortion if the adoption service has no parents who want to adopt the child.

Pupilc can mostly find out the correct answers. They use hermeneutical and logical proceedings: "For me it was B, [...] because Lisa now has not only the choice between abortion and keeping the child, but she can also choose adoption." (m. 16) Other respondents approached the answer via an exclusion procedure, in which they check the content of the text and they choose the most likely solution.

In this task the will is also part of the arguments: "But I think, if you see your own child and then release it for adoption, probably you want the child for yourself / Then comes the time when you want to get to know the child yourself (.) And you want to be there for the child." In this quote, the pupil also considers the consequence of the act. As the close union between the child and mother is still existing in the eyes of the pupil, the options for making decisions do not really get better. This argument is about one's own will and not the weighing of different wills. For other pupils it is difficult to pick an answer, therefore they do not give an answer.

Concerning the second research question we can say that in a lot of tasks the pupil's discussions deal with the will. Sometimes pupils can distance themselves from their own will, sometimes they cannot.

Concerning the third and fourth research questions: We can find, periagogic, categoric, socialcritic and pragmatic arguments in pupils answers. These theoretical types of decision are supplemented by the following categories. The first three names of categories that were found in pupils discussions are based on the classification of ethical reasons by Annemarie Pieper (2007). The dialectic / discourse way of decisions is partly caused in the setting of the research. Pupils discuss various arguments and make a consensus. A logical decision is, when by prior knowledge of other or related content on a new content in the task can be concluded. A special case of logical reasoning is the decision for a specific answer according to the exclusion criterion. In doing so, answers that are considered unlikely are eliminated, and pupils select the answer that has not been eliminated. In the hermeneutical decisions meanings of words are analysed and details in the tasks are used to find the correct answer. 
Different to the logical method, the hermeneutical approach is based on information in the task. The meaning of words is analysed and details in the tasks are used to get the correct answer. This approach corresponds to the expected problem solving strategies in the ETiK-Test. (Heynitz, 2016)

In a further ethical argumentation found in the discussions, pupils compare values and goods and they make a hierarchy of these values and goods. This way they come to a decision by weighing different values. Another category of ethical arguments is "critical of religion". Here theistic arguments are rejected, for example when they argue against religious commandments. When tasks are very complicated, pupils sometimes resign. They choose any answer because they do not want to think about it anymore, they give up.

Moral arguments in which pupils refer to a relation point, are used more often than ethical argumentations. Reference points can be one's own experiences, facts (real or supposed), consequences of actions or one's own feelings. Another domain is the reference to codices. As shown above the dealing with one's own and someone else's will (Herbart 1808; Benner 2016) is part of codices..

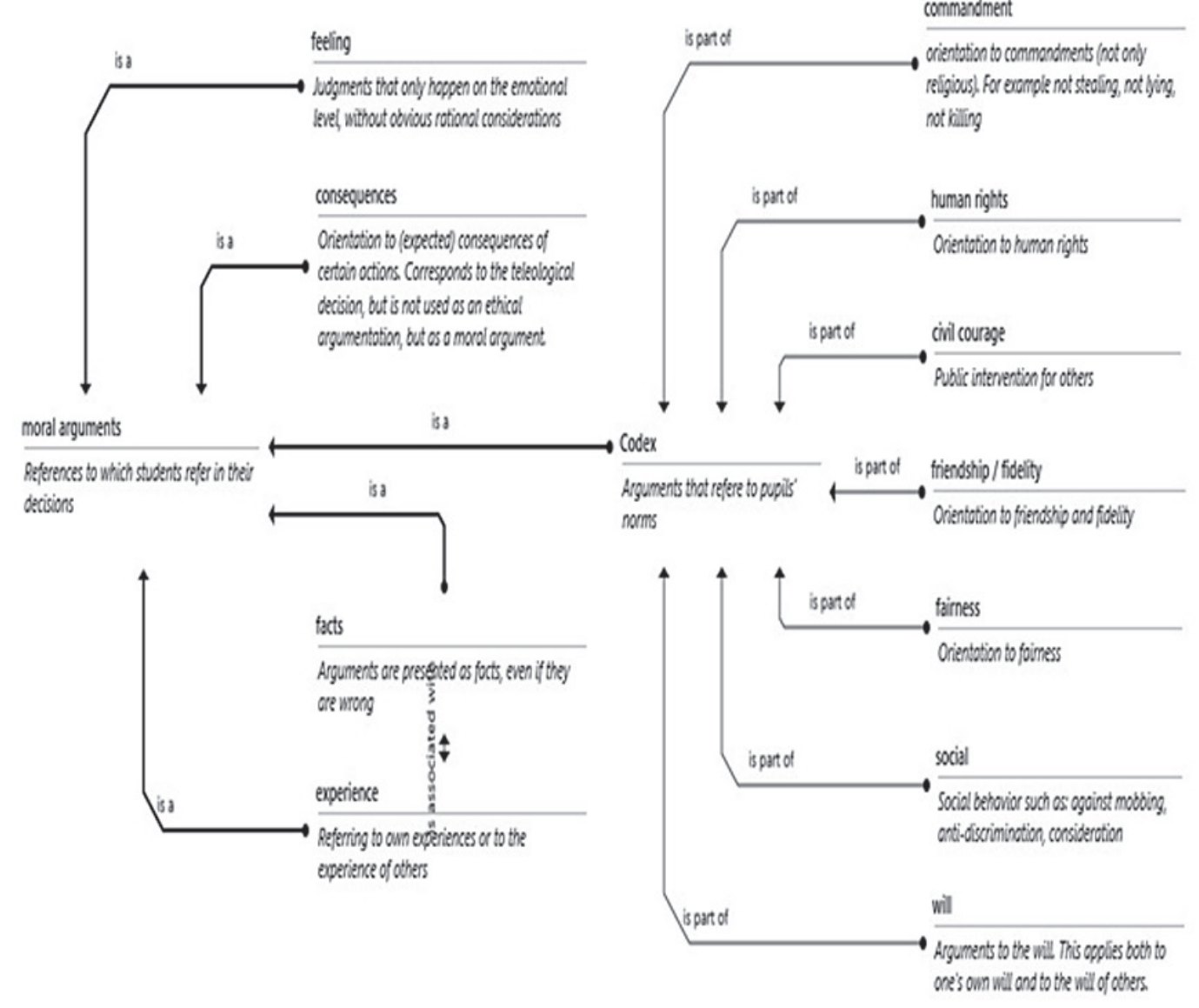

Fig. 2 Moral arguments

Source: own elaboration. 
Using facts as arguments is combined with arguments referring to pupil's experiences because experiences generate subjective factuality.

Arguments that bear in mind consequences are teleological processes of decisions (ethical argumentations). But in discussions pupils do not focus on the process of reasoning, they point at the consequences of an activity as a moral instance. Therefore, these statements are set as moral arguments. Pupils, for example, never say that an end justifies the means, this would be an ethical argument behind these moral arguments. Yet pupils often refer to the expected consequences of certain actions.

When arguing, pupils sometimes refer to their own feelings. When they do so, this is accepted by classmates in most of the passages.

The code "Codex" is presented more in detail, because it has seven subcategories and one of these subcategories is called "will".

Fairness plays a central role in the respondents and can be seen as an ethical principle (Pieper, 1991). Also, friendship and fidelity are topics which are often mentioned. That one must not betray other persons and that promises are to be kept is always connected with friends, therefore these statements are included in the Codex "friendship and faithfulness".

From the pupil's statements that one should not lie, steal and kill, the category "commandments" was created, which is not to be interpreted religiously.

In the case of moral courage, the focus is on an active commitment to other people (Meyer, 2004; Zitzmann, 2010). Moral courage is mostly related to human dignity and human rights. The human rights category includes statements referring to general norms such as the demand for equal rights for all people, freedom of opinion and expression, freedom of assembly, human dignity and the right to live. Norms within the code "social" are labelled as standing against mobbing, against discrimination and for consideration.

As already shown, the will has been a central topic for creating tasks. In our data-based category system, this central dimension is part of a system of norms, to which pupils refer. This is caused of the pupils making the will to a norm. Within the category "will", two different subcategories can be found in the discussions. In the one subcategory decisions are made according only to one's own will. Further statements also refer to the will of others. The inclusion of the will of other persons corresponds to the ideas of elemental judgements from Herbart ( Herbart, 1808; Benner et al., 2015; Benner \& Nikolova 2016). The discussions are not about the metalevel of justifying a decision. One's own will, or the will of another person is set as reference.

\section{Discussion of results and conclusion}

This article deals with the question of whether the theoretical basics of the ETiKTest (Benner \& Nikolova, 2016) can be found empirically in pupils' discussions 
about tasks in the test. In order to validate the test two studies were developed. A quantitative research to analyse the structural validity and a qualitative research to analyse the content-related validity. (Ritzer, 2019) This text concentrates on the results of the qualitative investigation. In order to analyse the content-related validity pupils were asked to justify their answers in the multiple choice-test.

Most of the ethical argumentations match the theory of Benner and colleagues, which is based on various philosophical traditions (Benner, 2016). We could find periagogic, categoric, socialcritic and pragmatic arguments. The dialectic / discourse way of decisions, logical and hermeneutic decisions are formulated according to the classification by Annemarie Pieper (2007). New judgements formulate considerations of values \& goods and criticism of religion.

Concerning moral arguments handling the will is a central topic. This is related to the elementary judgements from Herbart (1808). In pupils' arguments, we can find the weighing for different wills as well as decisions that only comply with their own will.

From the perspective of comprehensibility of the tasks, the qualitative research shows that some tasks are difficult to be solved. Known items should not have a negation in the text (Jonkisz et al., 2012). This is also shown in the ETiK-Test, because these tasks which have a negation are very difficult for the pupils to solve, just like tasks that have complicated formats.

In summary, it can be said that the ETiK-Test so far is the only test that measures ethical-moral competences based on education-theoretical, ethical and subjectdidactical considerations and that goes beyond self-assessment. Anotherunique feature of the ETiK-Test is that the use of the items-response theory makes adaptive testing possible.

If pupils discuss and justify their answers, the answers correspond to the basic theoretical concept. Sometimes incorrect response patterns can lead to correct answers and some task adaptions have to be made.

For further investigations, it would be interesting to show the tasks to experts in philosophical ethics and to reflect on the test tasks from their point of view.

\section{References}

Benner, D. (2016). Zur pädagogischen und erziehungswissenschaftlichen Begründung des Ansatzes. In D. Benner \& R. Nikolova (Eds.). Ethisch-moralische Kompetenz als Teil öffentlicher Bildung. Der Berliner Ansatz zur Konstruktion und Erhebung ethisch-moralischer Kompetenzniveaus im öffentlichen Erziehungsund Bildungssystem mit einem Ausblick auf Projekte zu ETiK-International (pp. 13-44). Paderborn: Schöningh.

Benner, D., \& Nikolova, R. (Eds.) (2016). Ethisch-moralische Kompetenz als Teil öffentlicher Bildung. Der Berliner Ansatz zur Konstruktion und Erhebung 
ethisch-moralischer Kompetenzniveaus im öffentlichen Erziehungs- und Bildungssystem mit einem Ausblick auf Projekte zu ETiK-International. Paderborn: Schöningh.

Benner, D., Oettingen von, A., Peng, Zh., \& Stępkowski, D. (2015). Bildung - Moral Demokratie. Theorien und Konzepte moralischer Erziehung und Bildung und ihre Beziehungen zu Ethik und Politik. Paderborn: Schöningh.

BMUKK (2012). Bericht der Bundesministerin für Unterricht, Kunst und Kultur Dr. Claudia Schmied gemäß Entschließung des Nationalrates vom 19.01.2012 betreffend Ethik-Unterricht. Retrieved from: https://www.parlament.gv.at/PAKT/VHG/ XXIV/III/III_00357/imfname_271036.pdf (28.7.2019).

Bucher, A. A. (2001). Ethikunterricht in Österreich. Bericht der wissenschaftlichen Evaluation der Schulversuche „Ethikunterricht". Innsbruck: Tyrolia.

Bucher, A. A. (2017). Die Notwendigkeit und Wirksamkeit ethischer Bildung. In F. Feiner, J. Krammer, I. Pack, M. Resnik, \& R. Straßegger-Einfalt (Eds.). Wert(e) voll wachsen. Ethische Bildung für eine nachhaltige, dialogische Zukunft. Graz: Leykam, LogoMedia.

Flick, U. (2016). Qualitative Sozialforschung. Eine Einführung. Reinbek bei Hamburg: Rowohlt.

Friese, S. (2019). ATLAS.ti 8 windows. User manual. Retrieved from: https://atlasti. com/2017/07/25/atlas-ti-8-windows-user-manual/ (18.06.2019).

Fuß, G., Jung, A., Kriesel, P., Goergen, K., Weil, G., \& Wentzkat, M. (2016). Denkschrift zum Ethikunterricht - Zwischen Diskriminierung und Erfolg. 44 Jahre Diskriminierung als „Ersatzfach“ im Westen, 25 Jahre Ethik als „Wahlpflichtfach“ im Osten, 20 Jahre Lebensgestaltung-Ethik-Religionskunde, 10 Jahre „Ethik für alle" in Berlin. Fachverband Ethik (Bundesverband). Retrieved from: //www. glaeserne-waende.de/media/2016/05/Denkschrift_Ethikunterricht_2016.pdf (28.7.2019).

Herbart, J. F. (1808). Allgemeine Practische Philosophie. Göttingen: Danckwerts Röwer.

Heynitz, M. (2016). Die Entwicklung von Testaufgaben zur Erhebung ethischmoralischer Grundkenntnisse, Urteils- und Handlungsentwurfskompetenz. In D. Benner \& R. Nikolova (Eds.). Ethisch-moralische Kompetenz als Teil öffentlicher Bildung. Der Berliner Ansatz zur Konstruktion und Erhebung ethisch-moralischer Kompetenzniveaus im öffentlichen Erziehungs- und Bildungssystem mit einem Ausblick auf Projekte zu ETiK-International (pp. 69-10o). Paderborn: Schöningh.

Hübner, D. (2014). Einführung in die philosophische Ethik. Göttingen: Vandenhoeck \& Ruprecht.

Ivanov, S. (2016). Die Validierung des ETiK-Instruments. In D. Benner \& R. Nikolova (Eds.). Ethisch-moralische Kompetenz als Teil öffentlicher Bildung. Der Berliner Ansatz zur Konstruktion und Erhebung ethisch-moralischer Kompetenzniveaus im öffentlichen Erziehungs- und Bildungssystem mit einem Ausblick auf Projekte zu ETiK-International (pp. 101-129). Paderborn: Schöningh. 
Jonkisz, E., Moosbrugger, H., \& Brandt, H. (2012). Planung und Entwicklung von Tests und Fragebogen. In H. Moosbrugger \& A. Kelava (Eds.). Testtheorie und Fragebogenkonstruktion. Mit 66 Abbildungen und 41 Tabellen. 2., aktualisierte und überarbeitete Auflage. Berlin, Heidelberg: Springer.

Lamnek, S. (2010). Qualitative Sozialforschung. Lehrbuch. Weinheim, Basel: Beltz. Mayring, P. (2010). Qualitative Inhaltsanalyse. Grundlagen und Techniken. Weinheim, Basel: Beltz.

Mayring, P. (2016). Einführung in die qualitative Sozialforschung. Eine Anleitung zu qualitativem Denken. Weinheim, Basel: Beltz.

Meyer, G. (2004). Was heißt mit Zivilcourage handeln? In G. Meyer, U. Dovermann, S. Frech \& G. Gugel (Eds.). Zivilcourage lernen. Analysen - Modelle - Arbeitshilfen. Tübingen: Institut für Friedenspädagogik.

Nikolova, R. (2016). Zur bildungswissenschaftlichen Ausrichtung des Ansatzes. In D. Benner \& R. Nikolova (Eds.). Ethisch-moralische Kompetenz als Teil öffentlicher Bildung. Der Berliner Ansatz zur Konstruktion und Erhebung ethisch-moralischer Kompetenzniveaus im öffentlichen Erziehungs- und Bildungssystem mit einem Ausblick auf Projekte zu ETiK-International (pp. 45-68). Paderborn: Schöningh.

Pieper, A. (1991). Fairneß als ethisches Prinzip. Deutsche Zeitschrift für Philosophie, 39, pp. 7-12.

Pieper, A. (2007). Einführung in die Ethik. Tübingen, Basel.

Quante, M. (2013). Einführung in die Allgemeine Ethik. Darmstadt: WBG.

Ritzer, G. (2019). Ethisch-moralische Kompetenzen Messen. Validierung des Testinstrumentariums ETiK in Österreich anhand von Pretestungen. Dissertation Salzburg.

Ritzer, G., Breinbauer, I. M., Schluß, H., \& Krobath, T. (2016). ETiK-InternationalWien: Ethikunterricht und Religionsunterricht in Österreich: Forschungsfragen, Ansatz und Befunde der Validierungsstudie. In D. Benner \& R. Nikolova (Eds.). Ethisch-moralische Kompetenz als Teil öffentlicher Bildung. Der Berliner Ansatz zur Konstruktion und Erhebung ethisch-moralischer Kompetenzniveaus im öffentlichen Erziehungs- und Bildungssystem mit einem Ausblick auf Projekte zu ETiK-International (pp. 219-228). Paderborn: Schöningh.

Stępkowski, D., Ivanov, S., \& Ksionek, A. (2016). ETiK-International-Warschau. Ethik- und Religionsunterricht in Polen. Forschungsfrage, Ansatz und Befunde. In D. Benner \& R. Nikolova (Eds.). Ethisch-moralische Kompetenz als Teil öffentlicher Bildung. Der Berliner Ansatz zur Konstruktion und Erhebung ethisch- moralischer Kompetenzniveaus im öffentlichen Erziehungs- und Bildungssystem mit einem Ausblick auf Projekte zu ETiK-International (pp. 204-218). Paderborn: Schöningh.

Strauss, A., \& Corbin, J. M. (1996). Grounded theory. Grundlagen qualitativer Sozialforschung. Weinheim: Beltz. 
Zitzmann, C. (2010). Alltagshelden. Aktiv gegen Gewalt und Mobbing - für mehr Zivilcourage. Praxishandbuch für Schule und Jugendarbeit. Schwalbach: Wochenschau Verlag.

\section{ARGUMENTY ETYCZNO-MORALNE. WYNIKI BADANIA WALIDACYJNEGO TESTU ETIK}

Streszczenie: Prezentowany artykuł dotyczy wzorców etyczno-moralnych uobecniających się w argumentacjach uczniów wypełniających test ETiK. Główne pytanie dotyczy tego, czy odpowiedzi uczniów korelują z teoretycznymi rozważaniami konstruktorów tego testu. Jak wiadomo, test ETiK ma umożliwiać mierzenie kompetencji etyczno-moralnych uczniów na podstawie wiedzy etycznej uzyskanej przez nich na lekcjach etyki.

Najpierw omówiono teoretyczną koncepcję testu ETiK. Następnie autor przedstawia empiryczną metodę jakościową, którą zastosował w badaniu walidacyjnym. Na dwóch przykładach wyjaśnia procedurę badawczą. Po czym dokonuje przeglądu sposobów uzasadniania i form argumentacyjnych zastosowanych przez uczniów w odpowiedziach.

W badaniu wykazano, że główne założenia teoretyczne przyświecające twórcom testu ETiK odzwierciedlają się w przemyśliwaniach uczniów. Dla niektórych jednak form argumentacyjnych nie da się wskazać odpowiedników w koncepcji testu. Wskutek tego może się zdarzyć, że nieprawidłowe rozumowania moralne mogą być źródłem poprawnych odpowiedzi testowych i vice versa - prawidłowe rozumowania błędnych odpowiedzi.

Słowa kluczowe: kompetencje etyczno-moralne; test ETiK; walidacja kontekstualna; edukacja moralna.

Georg Ritzer is Professor at University College of Teacher Education on the KPH Edith Stein in Salzburg and private lecturer at the university of Salzburg. He studied theology and pedagogy. E-mail-address: georg.ritzer@kph-es.at 